\title{
EVALUATION OF DOSE DEPENDENT EFFECTS OF GAMMA RADIATION ON RAT TONGUE INTERNAL STRUCTURES: HISTOMORPHOMETRIC AND IMMUNOHISTOCHEMICAL STUDY
}

\author{
Khaled El-Sayed El-Haddad* and Hamdy Abdel Motagaly Metwaly**
}

\begin{abstract}
Introduction: Radiotherapy is one of the common modalities in management of head and neck cancers. However, many injurious effects were reported on unavoidable oral tissues in the radiation field including the tongue and its heterogeneous internal structure. It is important to define the optimum dose of radiation with minimal hazards on the healthy tissues along with classification of the tissues according to their radio-sensitivity.
\end{abstract}

Purpose: To evaluate histomorphometrically and immunohistochemically the dose dependent response of lingual internal structures of rats exposed to gamma radiation.

Materials \& Methods: Twenty-two adult male albino rats were divided into 3 groups: control group ( 6 rats), R1 group ( 8 rats) irradiated by 2.0 Gy whole-body gamma dose, and R2 group ( 8 rats) irradiated by $6.0 \mathrm{~Gy}$. The effects on lingual internal structures were investigated after 3 days by histomorphometric and immunohistochemical staining for Caspase-3 using light microscopy.

Results: There were a dose related changes in the minor salivary glands with more changes in serous glands. Mild changes were observed in muscles only at 6 Gy dose. The expression percentage of caspase- 3 protein was significantly increased in a dose dependent manner in both of the irradiated groups when compared with control group $\mathrm{P}<0.05$. Whereas, it was non-significant when compared the expression percentage of Caspase- 3 between the irradiated group R1 (2 Gy) and irradiated group R2 (6Gy) P $>0$.05. Conclusion: Gamma radiation especially 6 Gy dose adversely affects the internal structures of the tongue with the most affected are serous acini and the least are the muscle cells.

KEYWORDS: Gamma radiation, caspase-3, lingual glands, intrinsic muscles.

\section{INTRODUCTION}

Management of head and neck cancer comprises a blend of surgery, radiotherapy, and chemotherapy.
Despite highly improved radiotherapy technologies, the exposure of healthy normal tissues in the radiation field is unavoidable..$^{(1,2)}$ Radiotherapy

* Lecturer, Department of Oral Biology, Faculty of Oral and Dental Medicine, Ain Shams University.

** Associate professor, Department of Oral Pathology, Faculty of Dentistry, Tanta University, Egypt. 
negatively affects several oral and paraoral tissues including skin, mucosa and bone tissues. ${ }^{(3)}$ In addition, radiation was reported to be a causative factor in hard dental tissues defects ${ }^{(4)}$ as well as delayed teeth eruption ${ }^{(5)}$ along with being a potent carcinogen. ${ }^{(6)}$

One of the normal tissues accidentally exposed to radiation is the tongue; the covering mucosa of the tongue and other oral structures are relatively well covered in the literature particularly regarding radiation induced oral mucositis which is considered one of the most frequent radiotherapy complications. ${ }^{(7,8)}$ On the other hand, relatively less concern was directed to the radiation effects on the internal structures of the tongue such as the intrinsic muscles and minor salivary glands. However, several studies were conducted to evaluate the radiation induced damage on major salivary glands ${ }^{(9-12)}$ and skeletal muscles of different regions. ${ }^{(13-19)}$

Radiation-induced xerostomia is multi-factorial including damage to major and minor salivary glands and associated nerves as well as endothelium. ${ }^{(9)}$ Salivary glands are exquisitely sensitive to radiation where early (acute) effects occur within a few days or weeks of irradiation, due to high levels of cell death particularly the acinar cells. ${ }^{(20-22)}$ Thus, the affected human individuals display a 50-60\% loss of salivary flow within the first week of radiotherapy. $(10,23,24)$ The onset of radiation induced damage is more rapid in rodents, hence, only 24 hours after radiation exposure, mouse parotid glands have about $30 \%$ apoptosis after a single 5-Gy exposure, compared with $15 \%$ after a single $1-G y$ dose. ${ }^{(25,26)}$

The serous acini were reported to be degenerated and impaired by radiation doses in an acute manner. Moreover, chronic salivary gland dysfunction has been attributed to these changes in serous acinar cells and replacement by connective tissue and fibrosis. ${ }^{(27-30)}$ The exact cause for acinar cell loss following irradiation has been widely debated. Previous work in the rat revealed radiation- induced apoptosis by counting condensed nuclei and reported 2-3\% apoptotic cells 6 hours after treatment within range of doses (2.5-25 Gy). (31) Dose-dependent radiation-induced apoptosis was detected in mice serous acini with significantly higher levels detected by immunohistochemistry against activated caspase-3. ${ }^{(25,26)}$

Regarding radiation effects on the skeletal muscles in general, patients previously were subjected to radiotherapy develop severe atrophy and weakness of the neck muscles mostly by myogenic damage. (32) On the other hand, investigations about how radiation can directly affect skeletal muscle morphologically and functionally are relatively few. Some authors claimed that gamma radiation induces muscle cell apoptosis. ${ }^{(33)}$ Others reported that radiation impairs the activation, proliferation and differentiation of muscle satellite cells, as well as interfering in membrane permeability and affecting sodium and potassium pump. ${ }^{(34)}$ More recently dose dependent DNA damage induced by gamma radiation in the fish muscle tissues was reported. ${ }^{(35)}$ Indirect muscle damage caused by an extrinsic factor such as progressive microvascular fibrosis was also concluded in previous work. ${ }^{(32)}$

For the lingual muscles in particular, it was observed that radiotherapy may be accompanied by swallowing complaints mostly caused by to muscular fibrosis and edema as well as formation of excess fibrous connective tissue. ${ }^{(36,37)}$ Moreover, tongue strength is reduced following head and neck radiotherapy. ${ }^{(38,39)}$ Radiation is also associated with a significant down regulation of tongue force production along with abridged speed of tongue muscle contraction. ${ }^{(40)}$ However, most of the previous work was directed mainly on the effect of gamma radiation on the extrinsic muscles of the tongue rather than intrinsic.

The limited work on the effect of gamma radiation on the minor salivary glands of the tongue along with the lingual intrinsic muscles lead to the requisite to more specified work in this field. In the present 
work, we aimed to study histomorphometrically and immunohistochemically the dose dependent response of lingual internal structures (minor salivary glands, muscles and connective tissue) of rats exposed to gamma radiation and to correlate between the dose of radiation and tissue response.

\section{MATERIALS AND METHODS}

\section{Materials}

Twenty-two adult male albino rats of average 250 grams weight were housed in wire mesh cages under controlled temperature. The experimental procedure was conducted in compliance with ethical principles for animals' research, which has matched the institutional guidelines of the Bioethical Committee of the Ain Shams University. The rats were divided into 3 groups: group 1 (control group), 6 healthy non-irradiated rats. The other 16 rats were irradiated, group R1; 8 rats were subjected to $2 \mathrm{~Gy}$ gamma radiation dose and group $\mathrm{R} 2 ; 8$ rats were subjected to $6 \mathrm{~Gy}$ gamma radiation dose. The irradiation process was performed in the Radiation Department in Atomic Energy Authority in Egypt.

\section{Sample preparation for histological examination}

All rats were killed 3 days after irradiation. Tongues were dissected and prepared for histological and immunohistochemical examinations. The tissue specimens were fixed in $10 \%$ neutral buffered formalin routinely processed and embedded in paraffin. Serial sections were cut at $5 \mu \mathrm{m}$ thickness, and one set of sections was stained with haematoxylin and eosin (H\&E) ${ }^{(41)}$ for histological examination and histomorphometric analysis. Another set of sections was used for immunohistochemical staining for Caspase-3 antibody.

\section{Immunohistochemistry:}

Immunohistochemical staining was performed using a peroxidase labeled streptavidin biotin complex. Five $\mu \mathrm{m}$ thick sections of paraffinembedded tissues were deparaffinized in xylene and routinely processed through ascending hydrated alcohol. Endogenous peroxidase activity was blocked with $0.3 \%$ hydrogen peroxide in methanol. Prior to immunostaining for antigen retrieval, the sections were pretreated with microwave in 10 $\mathrm{mM}$ citrate buffer ( $\mathrm{pH}$ 6.0) for 10-20 min followed by cooling at RT for 20 min then ultra V blocks were applied and the samples were incubated 5 minutes at room temperature to block nonspecific background staining. Mouse monoclonal antibodies for Caspase-3 (dilution1:200) diluted in phosphatebuffered saline (PBS) were applied directly to the slides and incubated at $4^{\circ} \mathrm{C}$ overnight. Primary antibody enhancer was applied then the samples were incubated for 10 minutes at room temperature and washed 4 times in buffer. HRP polymer was applied and samples were incubated for 15 minutes at room temperature and washed 4 times in buffer. One drop (40ul) DAB plus Chromogen was added to $2 \mathrm{ml}$ of DAB Plus Substrate, mixed by swirling and applied to the tissue then incubation for 5 minutes to visualize the reaction products then the slides were washed in deionized water 4 times. The sections were counterstained with hematoxylin. Positive controls of specimens of normal tissue were used. For negative control studies, the primary antibodies were replaced with normal mouse or rabbit IgGs.

\section{Histomorphometric and immunohistochemical analysis:}

Histomorphometric analysis was conducted by measuring the average size of the serous acini as well as the width of the connective tissue (lamina propria) in 5 regions in each slide.

The percentage of positive cells with Caspase-3 brown stain (positive reaction) to total number of cells at 400x magnification was calculated in five microscopic fields captured with a camera and the mean was determined automatically using MacBiophotonics ImageJ v.1.50e, quantitative immunohistochemical image processing and analysis software (National Institute of Health, Bethesda, Maryland, USA). 


\section{Statistical Analysis:}

The results were tabulated and statistically analyzed using statistical package for social science (SPSS for Windows, release 15.0; SPSS, Inc., Chicago, IL). Fisher's exact test and Student's t-test were used to obtain statistically significant differences between each 2 groups with $\mathrm{P}<0.05$ being considered statistically significant.

\section{RESULTS}

\section{Histological and histomorphometric results}

Examination of the muscle bundles in the samples of control group revealed regular longitudinal and transverse sections with peripheral nuclei and no signs of degenerations. Rats of group "R1" irradiated with 2 Gy displayed almost the same features of control group while those of group "R2" irradiated with 6 Gy showed signs of degenerative changes. Fragmented areas were frequently seen in the muscle bundles in addition to isolated fatty degeneration that was observed rarely (figure 1). The connective tissue underlying the dorsal surface of the tongue of control group showed dense fibrous tissue with non-congested blood vessels. On the other hand, both of the irradiated groups revealed some empty spaces infiltrating the connective tissue. Group "R2" showed apparent presence of inflammatory cells in addition to relative decrease in the width of the connective tissue from epithelium to the muscle fibers (figure 2).

Regarding the minor salivary glands, the mucous tubules of control group showed the characteristic foamy appearance with peripheral flat nuclei and well defined outline of the tubules. Almost similar findings were observed in irradiated group "R1". Group "R2" showed rather ill- defined margins of the mucous tubules with loss of cellular integrity in some regions (figure $3 \mathrm{~A}-\mathrm{C}$ ). Besides, the serous acini of control group showed dense contents and rounded nuclei and similarly were those of group "R1". On the other hand, in group "R2" there was a clearly seen distortion of the acini as well as heterogenicity of their staining and outlines along with apparent decrease in their size (figure $3 \mathrm{D}-\mathrm{F}$ ).

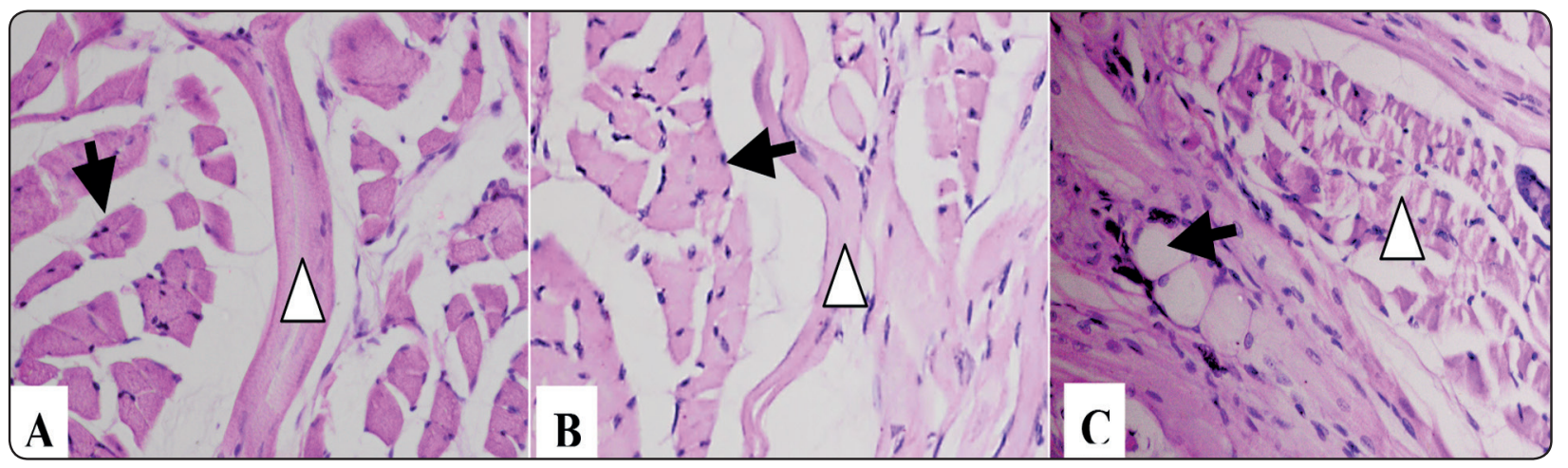

Fig. (1) Photomicrograph of muscle bundles of control group (A) and Group R1 (B) showing longitudinal sections (arrow heads) and cross sections (arrows) of muscle bundles. Group R2 (C) with fragmented fibers (arrow head) and fatty degeneration (arrow) (H\&E x 400). 


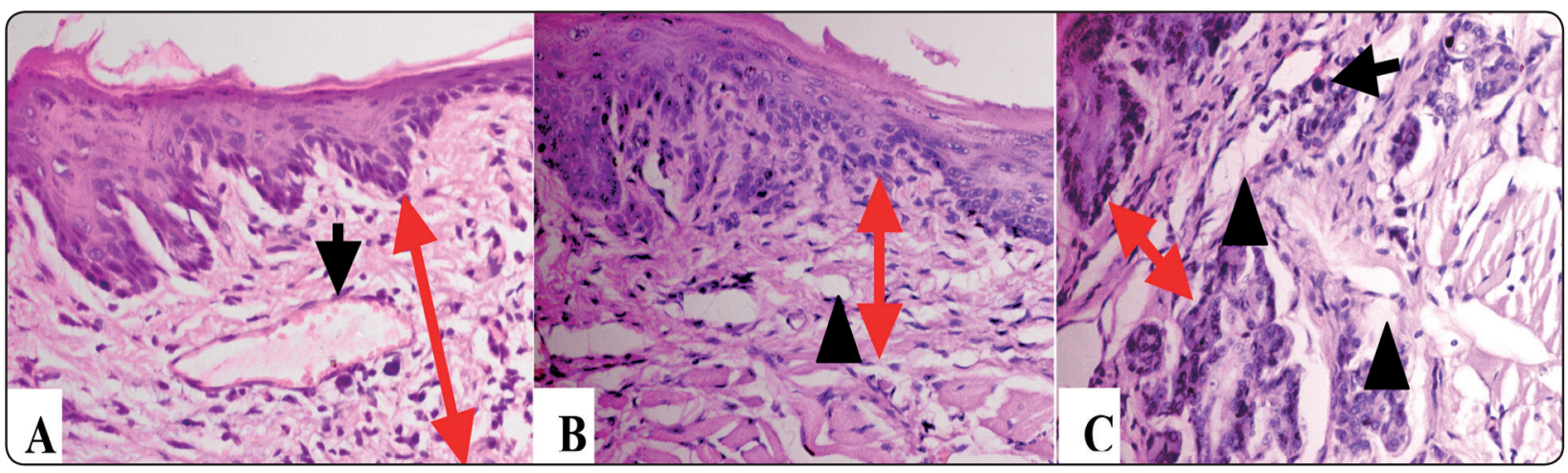

Fig. (2) Connective tissue of control group (A) with non-congested blood vessel (black arrow). Group R1 (B) showing minute empty spaces (arrow head) and group R2 (C) with wider spaces (arrow heads) and inflammatory cells (black arrow). Note the red double ended arrows to reveal the difference in connective tissue width (H\&E x 400).

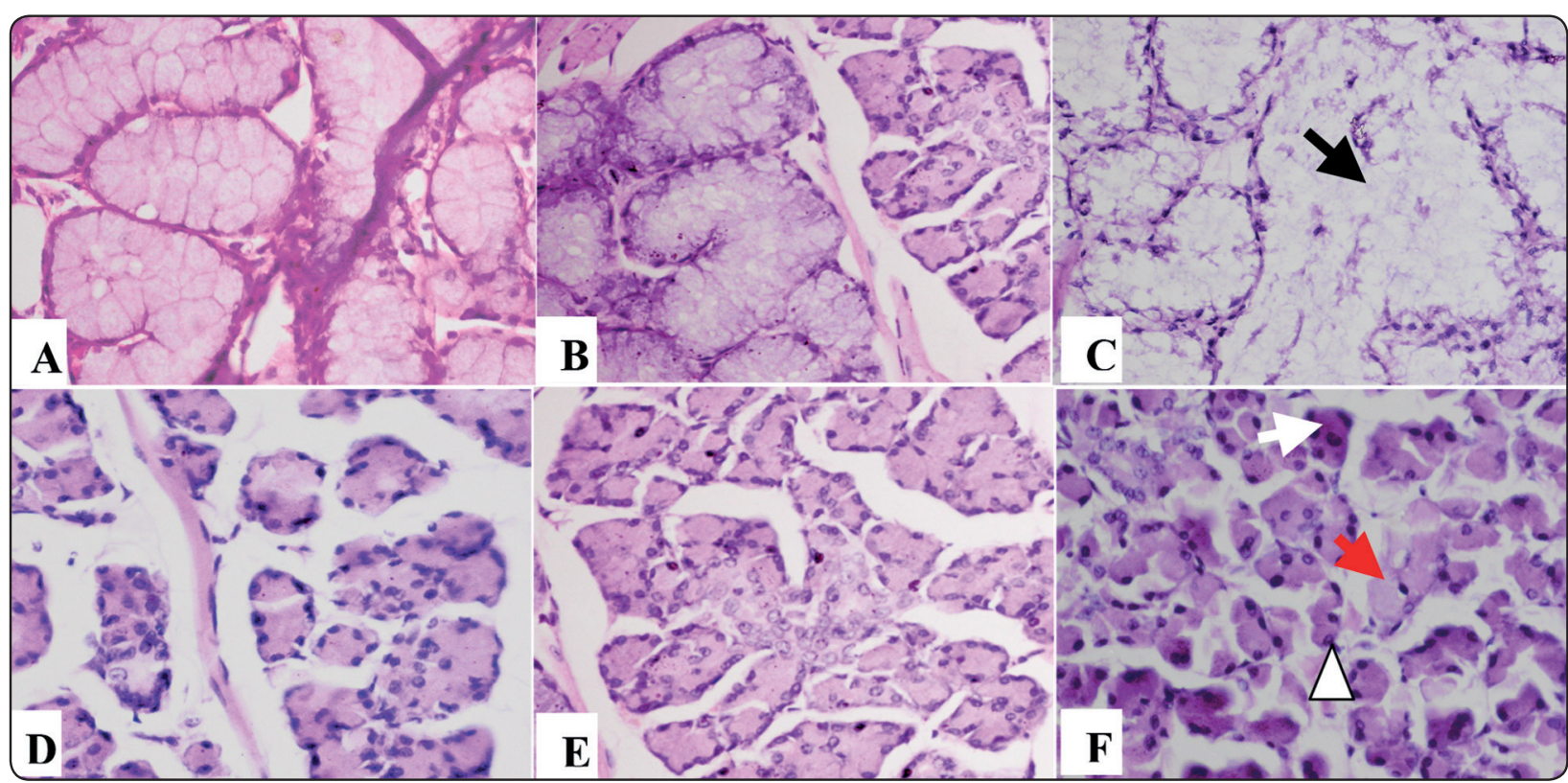

Fig. (3) Mucous tubules of control group (A) and group R1 (B) with foamy appearance. Group R2 (C) with hyaline appearance (arrow) and ill-defined margins. The serous acini of control group (D) and Group R1 (E) showing dense regular acini while group R2 (F) had distorted acini (arrow head) and deep stained (white arrow) and pale stained (red arrow) (H\&E x 400).

The average width of the connective tissue and the average size of the serous acini were measured using Image $\mathbf{J}$ analyzer. The mean values of both connective tissue width and serous acini size were descending from control group, group R1 till group R2 respectively (table 1) and (figure 4). The difference between each two groups in table (1) showed that the difference in connective tissue width was statistically significant in the comparison between control group and group R1 and between control group and group R2. While the difference in the serous acini size was statistically non-significant in all comparisons. 
TABLE (1): The mean values of serous acini size and connective tissue width in control and irradiated groups

\begin{tabular}{|c|c|c|c|c|c|c|c|c|c|}
\hline & \multicolumn{2}{|c|}{$\begin{array}{l}\text { Mean value of Size } \\
\left(\mathrm{um}^{2}\right) / \text { width (um) }\end{array}$} & \multirow[t]{2}{*}{$P$ value } & \multicolumn{2}{|c|}{$\begin{array}{c}\text { Mean value of Size }\left(u^{2}\right)^{2} / \\
\text { width (um) }\end{array}$} & \multirow[t]{2}{*}{$P$ value } & \multicolumn{2}{|c|}{$\begin{array}{l}\text { Mean value of Size } \\
\left(\mathrm{um}^{2}\right) / \text { width (um) }\end{array}$} & \multirow[t]{2}{*}{$P$ value } \\
\hline & Control & $2 \mathrm{~Gy}$ & & Control & $6 \mathrm{~Gy}$ & & $2 \mathrm{~Gy}$ & $6 \mathrm{~Gy}$ & \\
\hline $\begin{array}{l}\text { Serous acini size } \\
\qquad\left(\mathrm{um}^{2}\right)\end{array}$ & 836.33 & 782.71 & 0.170 & 836.33 & 744.83 & 0.155 & 782.71 & 744.83 & 0.811 \\
\hline $\begin{array}{l}\text { Connective tissue } \\
\text { width (um) }\end{array}$ & 151.97 & 128.06 & $0.049 *$ & 151.97 & 124.94 & $0.026^{*}$ & 128.06 & 124.94 & 0.807 \\
\hline
\end{tabular}

* significant.

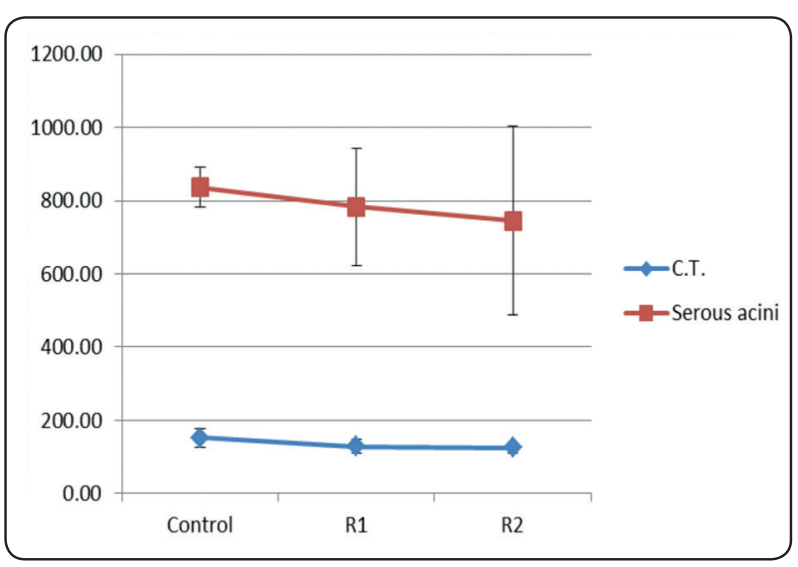

Fig. (4) Change in connective tissue width and serous acini size in the control and irradiated animals. There is decrease in both of parameters in irradiation groups $(\mathrm{R} 1, \mathrm{R} 2)$ as compared to control groups.

\section{Immunohistochemical results:}

The expression of caspase-3 was observed as brown staining in nuclei and cytoplasm of investigated tissues with different degree of intensity and distribution depending on the type of tissue and dose of radiation. The mean expression percentage of Caspase-3 was increased in all tissues in 6 Gy and $2 \mathrm{~Gy}$ irradiated groups when compared with the control groups (figure 5).

In control group the expression in mucous and serous cells was observed in nuclei and the mean expression percentage of Caspase- 3 was $15.025 \%$

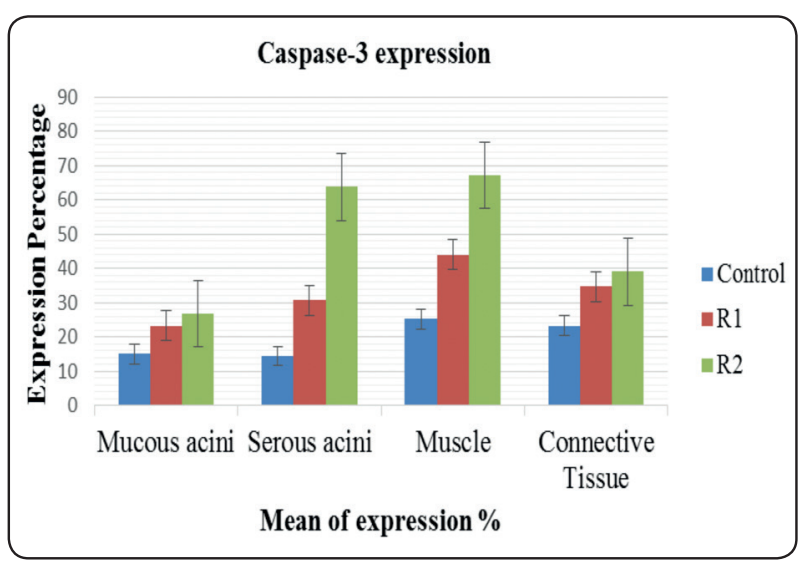

Fig. (5) Caspase-3 expression percentage of tongue tissues in control and irradiated animals. There is increased expression percentage of Caspase-3 in irradiation groups (R1, R2) as compared to control groups. The expression percentage increased when the dose is increased.

in mucous acini and it was $14.5 \%$ in serous acini (figure 1A,B) (table 2). In muscle tissues, the expression was weak and observed in the nuclei and the cytoplasm and the mean expression percentage was $25.225 \%$ (figure $6 \mathrm{~A}$ ) (table 2). In connective tissues, the expression of Caspase- 3 was observed in fibroblasts and the endothelial cells of blood vessels and the mean expression percentage was $23.35 \%$ (figure 7 B) (table 2).

In animals treated with $2 \mathrm{~Gy}$ radiation dose, the expression of Caspase-3 was increased in intensity and distribution when compared with control 
group. The mean of expression percentage was not significantly increased when compared with control group $P>0.05$ (table 2).

In animals treated with $6 \mathrm{~Gy}$ radiation dose, the expression of Caspase-3 was increased in intensity and distribution when compared with both control group and the $2 \mathrm{~Gy}$ radiation treated group. There was a significant difference when comparing the mean expression percentage of Caspase- 3 in 6Gy irradiation group with the control group in mucous acini and muscle tissue while it was highly significant in serous acini and the connective tissue $P<0.05$ (table 2). Although the mean expression percentages of Caspase-3 in 6Gy irradiation group was increased as compared to that of $2 \mathrm{~Gy}$ irradiation group, there were no significant differences $P>0.05$ (table 2).

TABLE (2): The mean expression percentage of Caspase-3 in control and irradiated groups

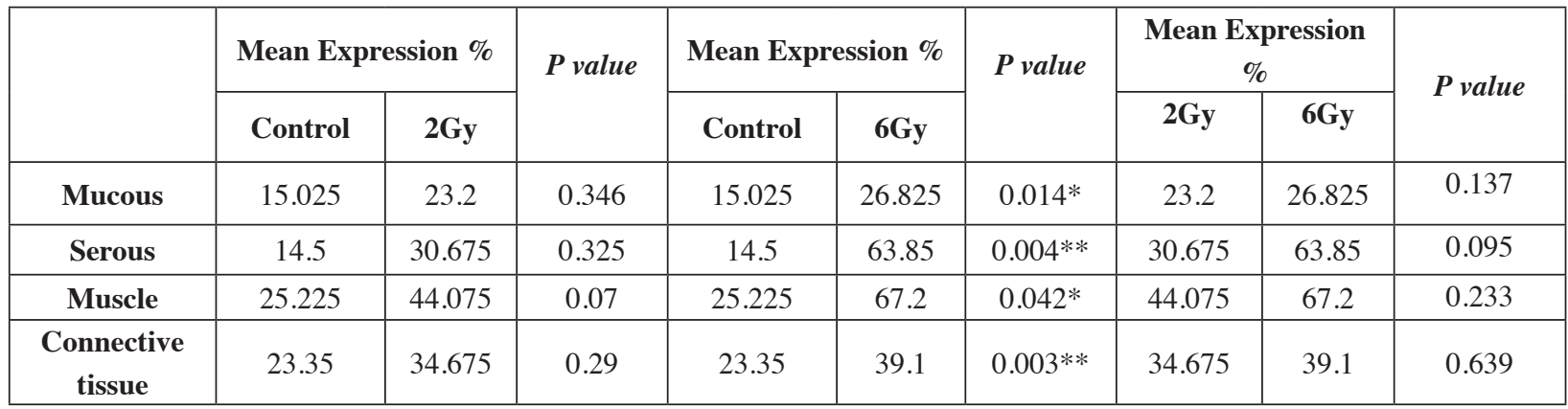

*significant ** highly significant

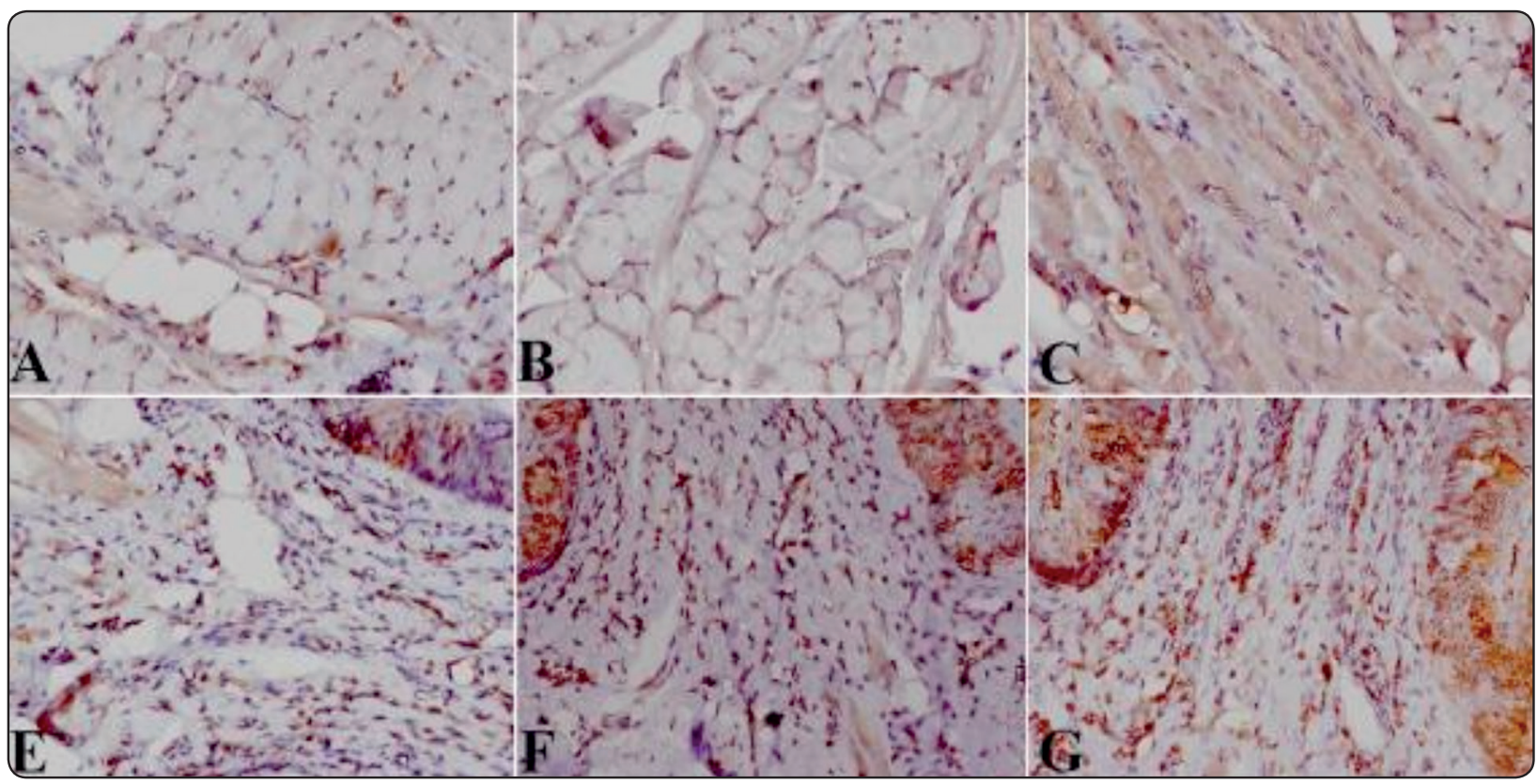

Fig. (6) Immunohistochemistry for Caspase-3 in muscle tissue (A-C) and connective tissue (E-G) of the tongue in control and in animals treated with irradiation $(\mathrm{R} 1, \mathrm{R} 2)$. Hematoxylin counterstain. Positive weak expression for Caspase-3 observed in control group (A \&E). In irradiation groups the expression was increased in group R1 (B \& F) and more increased in group R2 (C \&G). X400 


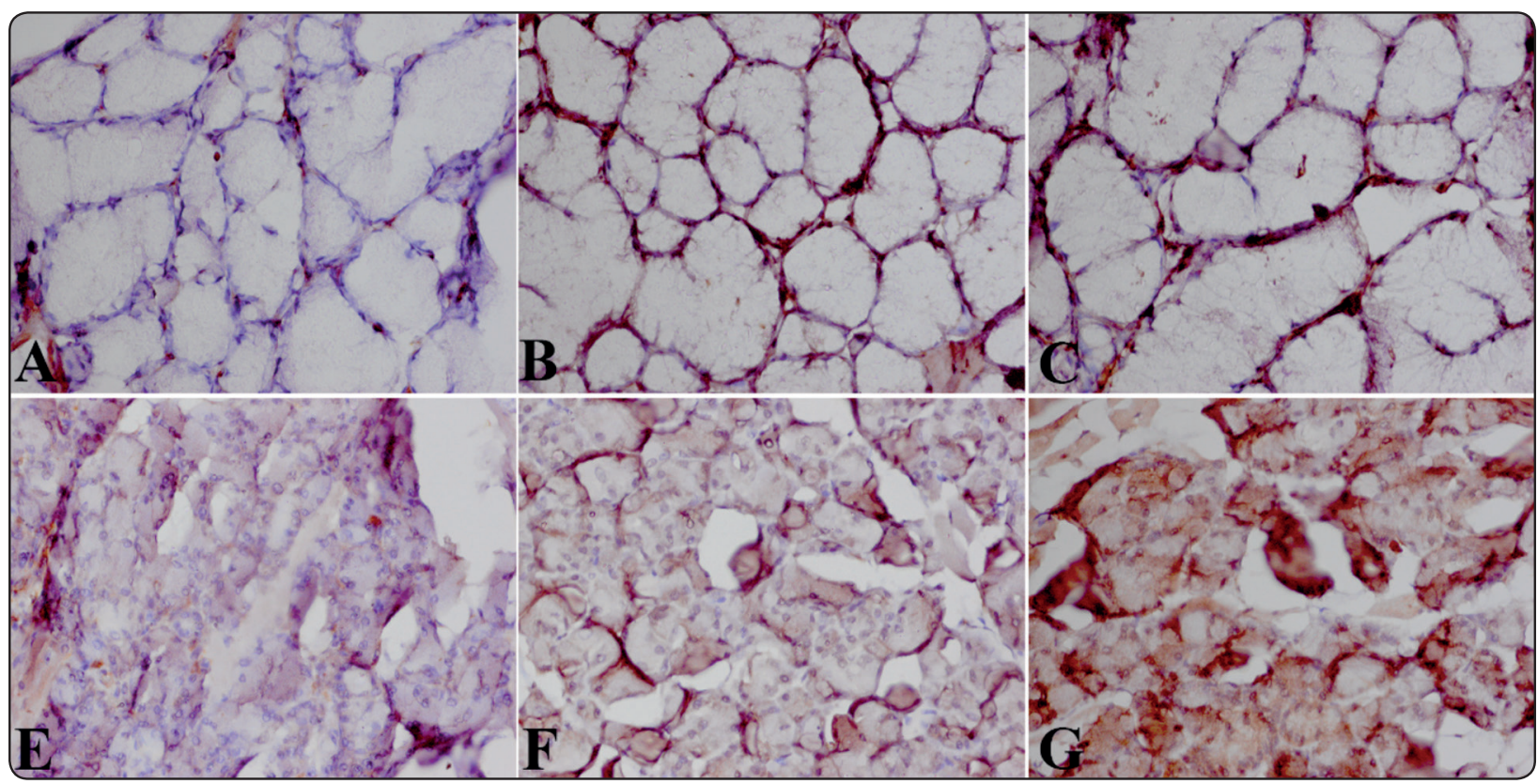

Fig. (7) Immunohistochemistry for Caspase-3 in mucous Acini (A-C) and in serous acini (E-G) of the tongue in control and in animals treated with irradiation (6Gy, 2Gy). Hematoxylin counterstain. Positive weak expression for Caspase-3 observed in control group (A \&E). In irradiation groups the expression was increased in 2 Gy radiation group (B \& F) and more increased in 6Gy irradiation group $(\mathrm{C} \& \mathrm{G})$. X400

\section{DISCUSSION}

The present work was conducted to evaluate gamma radiation effects on the internal structures of rat tongue. We performed animal model study due to the easy handling and conciseness of the effects observation, and physiological similarity to humans. ${ }^{(42,43)}$ We used 2 doses of gamma radiation, one is $2 \mathrm{~Gy}$ as the conventional head and neck cancer radiotherapy involves daily fractionation (2 Gy per fraction) over the course of several weeks (usually 7 weeks) ${ }^{(44,45)}$ and the second was $6 \mathrm{~Gy}$ dose to evaluate the dose dependence of radiation effects. We performed single dose radiation model, as the ability to criticize the mechanisms involved in salivary gland dysfunction is relatively limited in fractionated radiation studies; thus, studies using an appropriate single dose might donate greatly. ${ }^{(46)}$

The tongue is a complex muscular organ encloses both serous and mucous minor salivary glands embedded between the intrinsic muscles which made this organ responds to external irritants as radiation in a heterogenous manner according to the radio-sensitivity of each tissue. Interestingly, we observed different responses histologically and immunohistochemically in the different tissues. This coincides with the scale of radiosensitivity presented by Grundmann et al., $2009^{(46)}$ who reported that the muscles are more radio-resistant in comparison to oral mucosa whereas salivary glands are radiosensitive in relation to the former two tissues.

In the present work, we demonstrated that the serous acini were the most affected structure in the studied ones. Distortion of acini, decrease in size and increased apoptosis in a dose dependent manner were displayed which support the previous findings ${ }^{(20-22,47,48)}$ however, most of these studies were directed to the major salivary glands which entails the need for our work to confirm whether the same effects occurs in the minor salivary glands. We observed that degenerative changes in the serous acini were more evident statistically in rats irradiated with 6 Gy. This is in accordance to Vissink et al., 
1990 who reported that single dose of 5 Gy causes $40 \%$ reduction in salivary flow rates. ${ }^{(49)}$ Moreover, the most consistent observations reported in animal models were the decrease in flow rate and glandular weight along with loss of acinar area. $(27,29,49,50)$ Our work could be an addition to the explanation of the previously reported radiation-induced xerostomia. ${ }^{(9)}$

In the present work, the rats were sacrificed 3 days after radiation, however, observable changes were detected. This is in agreement with previous work who stated that early effects as cell death may occur within a few days after irradiation. ${ }^{(20-22)}$ the present results revealed apoptotic changes in salivary glands which coincide with other work on rodents where apoptosis was detected 24 hours after radiation exposure with doses ranges starting from 2.5 Gy. ${ }^{(25,26,31)}$

In the present study, we observed mild changes histologically but relevant apoptotic changes in the tongue muscles. The effects of gamma radiation on skeletal muscles of different regions were reported previously. ${ }^{(13-19)}$ However, these studies revealed different pattern of changes, which might be attributed to the difference in the species and/ or the studied muscles. The explanation of the muscle response to gamma radiation could be the apoptotic changes that were evident in our work by immunohistochemical examination. This is in agreement with some authors reported radiationinduced muscle cell apoptosis. (33) Our results might shed light on the mechanism of swallowing complaints \& reduced tongue strength accompanied by radiotherapy. ${ }^{(36-40)}$

We suggested that there is an indirect pathway of muscle impairment involving the distressing effects of radiation observed in our work in the connective tissue surrounding the tongue. This effect on the connective tissue coincides with $\boldsymbol{E}$ Saadany et al., 2017 who presented radiationinduced mucositis of rat tongue. (51) However, the detected immunopositive reaction in our results matches the results of Lee et al., 2005 who detected caspase expression in the muscles of the irradiated rats. ${ }^{(52)}$ The present study could give a primary assessment of the dose dependent radiation effects on the lingual internal structures, however, more effort might be needed to evaluate the reversibility of these effects and the possible ways for protection of radiation-induced changes.

\section{CONCLUSIONS}

Within limitations of the present study, we can conclude that gamma radiation adversely affects the lingual intrinsic muscles, connective tissue and minor salivary glands. The serous glands are more radiosensitive than mucous while intrinsic muscles are the most radio-resistant structure of the tongue interior.

\section{REFERENCES}

1. Feng FY, Kim HM, Lyden TH, Haxer MJ, Feng M, Worden FP, Chepeha DB, Eisbruch A. Intensitymodulated radiotherapy of head and neck cancer aiming to reduce dysphagia: early dose-effect relationships for the swallowing structures. Int J Radiat Oncol Biol Phys. 2007; 68(5):1289-98.

2. Feng FY, Kim HM, Lyden TH, Haxer MJ, Worden FP, Feng M, Moyer JS, Prince ME, Carey TE, Wolf GT, Bradford CR, Chepeha DB, Eisbruch A. Intensity-modulated chemoradiotherapy aiming to reduce dysphagia in patients with oropharyngeal cancer: clinical and functional results. J Clin Oncol. 2010;28(16):2732-8.

3. Vissink A, Jansma J, Spijkervet FK, Burlage FR, Coppes RP. Prevention and treatment of the consequences of head and neck radiotherapy. Crit. Rev. Oral Biol. M. 2003;14:199-212.

4. El-Faramawy N, Magdy R, El-Haddad K, El-Zainy M. Effects of gamma radiation on hard dental tissues of albino rats: investigation by light microscopy. Radiat Environ Biophys. 2013;52:375-87.

5. El-Faramawy N, El-Haddad K, Ali M, Talaat M. Impact of gamma radiation on the eruption rate of rat incisors. Radiat Effe Def Solids. 2015;170(9):771-85. 
6. Bazyka SC, Finch IM, Ilienko O, Lyaskivska I, Dyagil N, Trotsiuk N, Gudzenko V, Chumak K, Walsh J, Wiemels MP, Little, Zablotska LB. Buccal mucosa micronuclei counts in relation to exposure to low dose-rate radiation from the Chornobyl nuclear accident and other medical and occupational radiation exposures. Environ Health. 2017;16:70-88.

7. Scully C, Epstein JB. Oral health care for the cancer patient. Oral Oncol Eur J Cancer. 1996;32:281-92.

8. Al-Ansari S, Zecha JA, Barasch A, de Lange J, Rozema FR, Raber-Durlacher JE. Oral mucositis induced by anticancer therapies. Curr Oral Health Rep. 2015;2:202-11.

9. Eisbruch A, Ten Haken RK, Kim HM, Marsh LH, Ship JA. Dose, volume, and function relationships in parotid salivary glands following conformal and intensity-modulated irradiation of head and neck cancer. Int J Radiat Oncol Biol Phys. 1999;45:577-87.

10. Henson BS, Eisbruch A, D'Hondt E, Ship JA. Two-year longitudinal study of parotid salivary flow rates in head and neck cancer patients receiving unilateral neck parotid-sparing radiotherapy treatment. Oral Oncol. 1999;35:234-241.

11. Friedrich RE, Bartel S, Holzhausen HJ, Lautenschlager C. The effect of external fractionated irradiation on the distribution pattern of extracellular matrix proteins in submandibular salivary glands of the rat. J Craniomaxillofac Surg. 2002;30:246-54.

12. Bussels B, Maes A, Flamen P, Lambin P, Erven K, Hermans $R$ et al. Dose-response relationships within the parotid gland after radiotherapy for head and neck cancer. Radiother Oncol. 2004;73:297-306.

13. Flann KL, LaStayo PC, McClain DA, Hazel M, Lindstedt SL Muscle Damage and Muscle Remodeling: No Pain, No Gain? The Journal of Experimental Biology. 2011;214:674-79.

14. Khan, MY. Radiation-Induced Changes in Skeletal Muscle. An Electron Microscopic Study. Journal of Neuropathology \& Experimental Neurology. 1974;33:42-57.

15. Kim JP, Khalmuratova R Jeon SY, Park JJ, Hur DG, Ahn SK, et al. Quantitative Analysis of Myosin Heavy Chain Expression Change in Laryngeal Muscle after Irradiation in Rats. Yonsei Medical Journal. 2011;52:158-64.

16. Jurdana M. Radiation Effects on Skeletal Muscle. Radiology and Oncology. 2008;42:15-22.

17. Hardee JP, Puppa MJ, Fix DK, Gao S, Hetzler KL, Bateman TA, et al. The Effect of Radiation Dose on Mouse
Skeletal Muscle Remodeling. Radiology and Oncology. 2014;48:247-56.

18. Phelan JN and Gonyea WJ Effect of Radiation on Satellite Cell Activity and Protein Expression in Overloaded Mammalian Skeletal Muscle. The Anatomical Record. 1997;247:179-88.

19. Rosenblatt JD, Parry DJ Gamma Irradiation Prevents Compensatory Hypertrophy of Overloaded Mouse Extensor Digitorum Longus Muscle. Journal of Applied Physiology. 1992;73: 2538-43.

20. Hall E. Radiobiology for the radiologist. 2000; 5th ed. Philadelphia: Lippincott, Williams and Wilkins.

21. Robar JL, Day A, Clancey J, Kelly R, Yewondwossen M, Hollenhorst $\mathrm{H}$, et al. Spatial and dosimetric variability of organs at risk in head-and-neck intensity-modulated radiotherapy. Int J Radiat Oncol Biol Phys. 2007;68:1121-30.

22. Hoebers FJ, Kartachova M, de Bois J, van den Brekel MW, van Tinteren H, van Herk M, et al. 99mTc Hynic-rh-Annexin $\mathrm{V}$ scintigraphy for in vivo imaging of apoptosis in patients with head and neck cancer treated with chemoradiotherapy. Eur J Nucl Med Mol Imaging. 2008; 35:509-18.

23. Eisbruch A, Kim HM, Terrell JE, Marsh LH, Dawson LA, Ship JA. Xerostomia and its predictors following parotidsparing irradiation of head-and-neck cancer. Int J Radiat Oncol Biol Phys. 2001;50:695-704.

24. Dirix P, Nuyts S, Van den Bogaert W. Radiation-induced xerostomia in patients with head and neck cancer: a literature review. Cancer. 2006;107:2525-34.

25. Limesand KH, Schwertfeger KL, Anderson SM. MDM2 is required for suppression of apoptosis by activated Akt1 in salivary acinar cells. Mol Cell Biol. 2006;26:8840-56.

26. Humphries MJ, Limesand KH, Schneider JC, Nakayama KI, Anderson SM, Reyland ME. Suppression of apoptosis in the PKCdelta null mouse in vivo. J Biol Chem. 2006;281:9728-37.

27. Stephens LC, King GK, Peters LJ, Ang KK, Schultheiss TE, Jardine JH. Acute and late radiation injury in rhesus monkey parotid glands. Evidence of interphase cell death. Am J Pathol. 1986;124:469-78.

28. Radfar L, Sirois DA. Structural and functional injury in minipig salivary glands following fractionated exposure to 70 Gy of ionizing radiation: an animal model for human radiation-induced salivary gland injury. Oral Surg Oral Med Oral Pathol Oral Radiol Endod. 2003;96:267-74.

29. Li J, Shan Z, Ou G, Liu X, Zhang C, Baum BJ, et al. Structural and functional characteristics of irradiation damage 
to parotid glands in the miniature pig. Int $\mathrm{J}$ Radiat Oncol Biol Phys. 2005;62:1510-16

30. Muhvic M, Bralic M, Curic S, Pezelj S, Borcic J, Tomac J. Imbalance between apoptosis and proliferation causes late radiation damage of salivary gland in mouse. Physiol Res. 2006;55:89-95.

31. Paardekooper GM, Cammelli S, Zeilstra LJ, Coppes RP, Konings AW. Radiation-induced apoptosis in relation to acute impairment of rat salivary gland function. Int J Radiat Biol. 1998;73:641-8.

32. van Leeuwen EM, Dorresteijn LD, Pillen S, Biesma DH, Vogels OJ, van Alfen N. Progressive Muscle Atrophy and Weakness after Treatment by Mantle Field Radiotherapy in Hodgkin Lymphoma Survivors. International Journal of Radiation Oncology *Biology* Physics. 2012;82:612-8.

33. Wilson V, Daniel L, Edvane B, Jonathan M, Karla L, Ademir A. Late Effects of Radiation on Skeletal Muscle: An Open Field of Research. Journal of Biomedical Science and Engineering. 2015;08:555-70.

34. Jurdana M. Radiation Effects on Skeletal Muscle. Radiology and Oncology. 2008;42:15-22.

35. Mk PK, Shyama SK, D’Costa A, Kadam SB, Sonaye BH, Chaubey RC. Evaluation of DNA damage induced by gamma radiation in gill and muscle tissues of Cyprinus carpio and their relative sensitivity. Ecotoxicol Environ Saf. 2017;144:166-70.

36. Wu CH, Hsiao TY, Ko JY, Hsu MM. Dysphagia after radiotherapy: endoscopic examination of swallowing in patients with nasopharyngeal carcinoma. Ann Otol Rhinol Laryngol. 2000;109(3):320-5.

37. Lazarus C. Tongue strength and exercise in healthy individuals and in head and neck cancer patients. Semin Speech Lang. 2006;27(4):260-7.

38. Peters LJ, Harrison ML, Dimery IW, Fields R, Goepfert H, Oswald MJ: Acute and late toxicity associated with sequential bleomycin-containing chemotherapy regimens and radiation therapy in the treatment of carcinoma of the nasopharynx. Int J Radiat Oncol Biol Phys. 1988;14(4):623-33.

39. Eisele DW, Koch DG, Tarazi AE, Jones B: Case report: aspiration from delayed radiation fibrosis of the neck. Dysphagia. 1991;6(2):120-2.

40. Russell JA, Connor NP. Effects of Age and Radiation Treatment on Function of Extrinsic Tongue Muscles. Radiation Oncology. 2014;9:254.4
41. Bancroft JD, Stevens A. Theory and Practice of Histological Techniques.forth edition, Churchill Living Stone, Edinbeelig London. 1996: 104-147.

42. Andreollo NA, Santos EF, Araujo MR, Lopes LR. Rat's Age versus Human's Age: What Is the Relationship?. Arquivos Brasileiros de Cirurgia Digestiva. 2012;25:49-51.

43. Quinn R. Comparing Rat's to Human's Age: How Old Is My Rat in People Years? Nutrition. 2005; 21:775-7.

44. Bourhis J, Etessami A, Wilbault P, Lusinchi A, Calais G, Lapeyre M, Pignon JP: Altered fractionated radiotherapy in the management of head and neck carcinomas: advantages and limitations. Curr Opin Oncol. 2004; 16(3):215-19.

45. Marcu LG. Altered fractionation in radiotherapy: from radiobiological rationale to therapeutic gain. Cancer Treat Rev. 2010;36(8):606-14.

46. Grundmann GC. Mitchell KH. Limesand Sensitivity of Salivary Glands to Radiation from Animal Models to Therapies. J Dent Res. 2009;88(10):894-903.

47. Limesand KH, Barzen KA, Sanders LA, Sclafani RA, Raynolds MV, Reyland ME, et al. . Characterization of rat parotid and submandibular acinar cell apoptosis in primary culture. In Vitro Cell Dev Biol Anim. 2003; 39:170-7

48. O'Connell AC, Lillibridge CD, Zheng C, Baum BJ, O'Connell BC, Ambudkar IS. Gamma-irradiation-induced cell cycle arrest and cell death in a human submandibular gland cell line: effect of E2F1 expression. J Cell Physiol. 1998;177:264-73.

49. Vissink A, 's-Gravenmade EJ, Ligeon EE, Konings WT. A functional and chemical study of radiation effects on rat parotid and submandibular/sublingual glands. Radiat Res. 1990;124:259-65

50. Nagler RM, Baum BJ, Miller G, Fox PC. Long-term salivary effects of single-dose head and neck irradiation in the rat. Arch Oral Biol. 1998;43:297-303

51. Elsaadany B, El Kholy S, El Rouby D, Rashed L, Shouman T. Effect of Transplantation of Bone Marrow Derived Mesenchymal Stem Cells and Platelets Rich Plasma on Experimental Model of Radiation Induced Oral Mucosal Injury in Albino Rats. Int J Dent. 2017;2017:8634540.

52. Lee MC, Wee GR, Kim JH. Apoptosis of skeletal muscle on steroid-induced myopathy in rats. J Nutr. 2005;135(7):1806-8. 